\title{
Evaluation of surgical procedures in primary mediastinal cysts and tumors: single-center experience
}

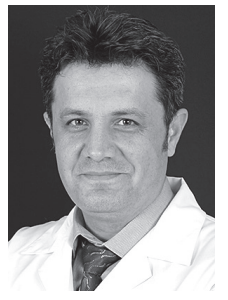

\author{
${ }^{1}$ Thoracic Surgery Clinic, Medicalpark Elazığ Hospital, Elazığ, Turkey
}

${ }^{2}$ Chest Diseases Clinics, Medicalpark Elazığ Hospital, Elazığ, Turkey

Kardiochir Torakochir Pol 2019; 16 (3): 109-113

\begin{abstract}
Aim: In this study, we aimed to evaluate the results of our patients with a primary mediastinal mass and the surgical techniques applied in our clinic retrospectively.

Material and methods: Between March 2015 and March 2019, the results and treatment protocols of 32 patients with a primary mediastinal mass or cysts who were followed up and treated in our clinic were evaluated retrospectively. Twenty-six patients who underwent surgery for biopsy or resection were included in the study.

Results: Sixteen of our patients were male and 10 were female. The mean age was 39 years. $80.2 \%$ of our patients were symptomatic and $19.2 \%$ were asymptomatic and a mediastinal mass was incidentally detected in these asymptomatic patients. The most common symptom was dyspnea with frequency of $38.4 \%$. In terms of localization, the mass was lateralized on the right side in 7 patients, on the left side in 5 patients. In 13 patients, the tumor was located in the posterior mediastinum. 8 patients underwent anterior mediastinotomy and 1 patient underwent biopsy with video-assisted thoracoscopic surgery (VATS). Most commonly a thymus-derived mass was seen. Fifteen patients underwent excision with VATS, 3 thoracotomy, 2 sternotomy and in 1 patient VATS assisted anterior minithoracotomy was performed.

Conclusions: Mediastinal tumors and cysts have different histopathological features. Robotic surgery and VATS-assisted surgery are increasingly used in surgical excision.
\end{abstract}

Key words: mediastinal masses, neurogenic, thymoma, lymphoma, seminoma.

\section{Introduction}

The mediastinum is located between the lungs, the posterior sternum, the anterior of the vertebral column, the thoracic inlet and the diaphragm [1]. It is examined in three parts as anterior, middle and posterior mediastinum [2].

\section{Streszczenie}

Cel: Celem pracy była retrospektywna ocena wyników leczenia pacjentów z pierwotnym guzem śródpiersia oraz technik operacyjnych stosowanych w klinice.

Materiał i metody: Retrospektywnej ocenie poddano wyniki i protokoły leczenia 32 pacjentów z pierwotnymi guzami lub torbielami śródpiersia, którzy byli obserwowani i leczeni w klinice autorów od marca 2015 do marca 2019 r. Do badania włączono 26 pacjentów, u których przeprowadzono biopsję lub resekcję chirurgiczną.

Wyniki: Grupa badana obejmowała 16 mężczyzn i 10 kobiet. Średni wiek uczestników badania wynosił 39 lat. U 80,2\% pacjentów występowały objawy, natomiast u 19,2\% choroba przebiegała bezobjawowo, a patologiczna masa w śródpiersiu została wykryta przypadkowo. Najczęstszym objawem (u 38,4\% pacjentów) była duszność. Pod względem lokalizacji guz był umiejscowiony po prawej stronie $u 7$ pacjentów, a po lewej stronie ciała u 5 pacjentów. U 13 pacjentów guz był umiejscowiony w śródpiersiu tylnym. U 8 pacjentów przeprowadzono mediastinotomię przednią, a u 1 chorego wykonano biopsję i wideotorakoskopię (VATS). Najczęściej stwierdzano guza wywodzącego się z grasicy. $U 15$ pacjentów wykonano resekcję zmiany metodą VATS, u 3 pacjentów torakotomię, u 2 pacjentów sternotomię, a u 1 minitorakotomię przednią z VATS.

Wnioski: Guzy i torbiele śródpiersia mają różny obraz histopatologiczny. Coraz częściej zabiegi chirurgiczne wykonywane są przy zastosowaniu metod robotycznych oraz wideotorakoskopowych.

Słowa kluczowe: guzy śródpiersia, neurogenny, grasiczak, chłoniak, nasieniak.

The mediastinum contains vital and vascular organs and very different histopathological tumors can be seen in this region of the thorax [3].

When the general patient population is considered, they are rare. It has been reported that it is asymptomatic

Address for correspondence: Tayfun Kermenli MD, Thoracic Surgery Clinic, Medicalpark Elazığ Hospital, Olgunlar mh. Atatürk Bulvarı No: 5 , 23700 Elazığ, Turkey, phone: +90 4242348000, e-mail: tayfunkermenli@gmail.com

Received: 4.05.2019, accepted: 28.08.2019. 
Table I. Distribution of symptoms at diagnosis (VCSS: vena cava superior syndrome)

\begin{tabular}{lcc} 
Symptoms & Number of patients $(n=26)$ & $\%$ \\
Dyspnea & 10 & 38.4 \\
\hline Chest pain & 8 & 30.7 \\
\hline Cough & 7 & 26.9 \\
\hline Hoarseness & 7 & 26.9 \\
\hline Fever & 6 & 23 \\
\hline Weakness & 6 & 23 \\
\hline VCSS findings & 1 & 3.8 \\
\hline Palpitation & 1 & 3.8 \\
\hline Low eyelid & 1 & 3.8 \\
\hline
\end{tabular}

at rates ranging from $9 \%$ to $17 \%$ at the stage of diagnosis in Chest Surgery and Chest Disease practice [4, 5]. In symptomatic patients dyspnea, cough and chest pain were the most common symptoms. Hormonally active tumors may present with secondary findings such as tachycardia or hypertension [6, 7].

\section{Aim}

In this study, we aimed to retrospectively evaluate the results of our patients with a primary mediastinal mass and the surgical techniques applied in our clinic.

\section{Material and methods}

Between March 2015 and March 2019, the results and treatment protocols of 32 patients with a primary mediastinal mass or cysts who were followed up and treated in our clinic were evaluated retrospectively. Patients were evaluated according to age, gender, symptoms at the time of presentation, physical examination findings, diagnostic examination methods, laboratory test results and pathology findings. Twenty-six patients who underwent surgery for biopsy or resection were included in the study. Patients who were referred for treatment with fine-needle aspiration biopsy or tru-cut biopsy and who had not undergone any surgical procedure for diagnosis or resection were excluded from the study.

\section{Results}

Sixteen of our patients (61.5\%) were male and 10 (38.5\%) were female. The mean age was 39 years (16-71). The mean age was 33.8 (16-62) in females and 42.3 (23-71) in males.

$80.2 \%$ of our patients were symptomatic and $19.2 \%$ were asymptomatic and a mediastinal mass was incidentally detected in these patients. The most common symptoms were dyspnea with a rate of $38.4 \%$, chest pain (30.7\%), cough (26.9\%) and voice hoarseness (26.9\%). Fever was present in $6(23 \%)$ and fatigue in $6(23 \%)$ patients. The main symptom was palpitation (7.6\%) in one patient with a posterior mediastinal mass diagnosed with pheochromocytoma. On physical examination, 1 patient had marked vena cava superior syndrome (VCSS). Tachycardia was observed in 1 patient, and wheezing and low eyelid were observed in one patient. The distribution of symptoms is given in Table I.

In all of our patients, radiological examination was performed by postero-anterior and lateral chest radiography after physical examination. When chest X-rays were evaluated retrospectively, 4 (15.4\%) patients had no positive findings and 22 (84.6\%) had a mediastinal mass. Contrast-enhanced thorax computed tomography (CT) was performed in all patients. Thorax magnetic resonance imaging (MRI) was performed in 1 (3.8\%) patient, who was considered to have a neurogenic tumor. Positron emission tomography-CT (PET-CT) was used for diagnosis and staging purposes in 13 patients who were thought to have a malignant mass. In 11 patients, PET-CT diagnosed malignancy and 2 patients were reported to have benign lesions. The mean SUVmax value was 11.6 (5.3-20.1) in PET-CT imaging.

Table II. Pathology results of patients and mediastinal localization of masses

\begin{tabular}{|c|c|c|c|c|}
\hline \multirow{2}{*}{\multicolumn{2}{|c|}{ Pathologic diagnosis }} & \multicolumn{3}{|c|}{ Localizations of tumors and cysts } \\
\hline & & Anterior mediastinum & Middle mediastinum & Posterior mediastinum \\
\hline \multirow[t]{6}{*}{ Benign } & Bronchogenic cyst & - & 2 & 3 \\
\hline & Thymic hyperplasia & 3 & - & - \\
\hline & Neurogenic tumor & - & - & 1 \\
\hline & Ectopic thyroid tissue & 1 & - & 1 \\
\hline & Hydatid cyst & - & 1 & - \\
\hline & Castleman's disease & - & 1 & - \\
\hline \multirow[t]{5}{*}{ Malign } & Lymphoma & 2 & 2 & - \\
\hline & Thymic carcinoma & 3 & - & - \\
\hline & Thymoma & 3 & - & - \\
\hline & Neurogenic tumor & - & - & 2 \\
\hline & Germ cell tumor & 1 & - & - \\
\hline
\end{tabular}


Table III. Surgical techniques for excision of tumors and cysts

\begin{tabular}{|c|c|c|c|c|}
\hline \multirow[t]{2}{*}{ Surgical techniques for excision } & \multicolumn{2}{|c|}{ Pathologic diagnosis } & \multirow{2}{*}{$\begin{array}{c}\text { Number of } \\
\text { patients }(n=21)\end{array}$} & \multirow[t]{2}{*}{$\%$} \\
\hline & Benign & Malign & & \\
\hline Video-assisted thoracoscopic surgery (VATS) & 11 & 4 & 15 & 57.7 \\
\hline Thoracotomy & 2 & 1 & 3 & 11.5 \\
\hline Sternotomy & - & 2 & 2 & 7.6 \\
\hline VATS supported anterior minithoracotomy & - & 1 & 1 & 3.8 \\
\hline
\end{tabular}

In terms of localization, 7 (26.9\%) masses were on the right side and 5 (19.2\%) were on the left side. In 13 (50\%) patients, the mass originated from the anterior mediastinum, 7 (26.9\%) from the posterior and 6 (23\%) from the middle mediastinum.

Eight $(30.7 \%)$ patients underwent anterior mediastinotomy and 1 (3.8\%) patient underwent video-assisted thoracoscopic surgery (VATS) for biopsy. Eleven (42.3\%) cases were diagnosed as malignant and 15 (57.7\%) were diagnosed as benign. One patient diagnosed with thymic carcinoma underwent surgical resection after neoadjuvant chemotherapy treatment. Four lymphoma patients were treated with chemotherapy alone.

In a patient with primary anterior mediastinal seminoma, no residual mass remained after chemotherapy and therefore no surgical resection was considered. Pathology results of the patients are given in Table II. The most common pathological origin was the thymus ( 9 patients, $34.6 \%)$. The most common benign lesion was bronchogenic cyst (5 patients, $19.2 \%$ ) and the most common malignant lesion was lymphoma (4 patients, 15.3\%).

When surgical techniques were evaluated, the rate of excision with VATS was $57.7 \%$ (15 patients), thoracotomy $11.5 \%$ (3 patients), sternotomy $7.6 \%$ (2 patients) and VATS supported anterior minithoracotomy $3.8 \%$ (1 patient). There was no postoperative mortality in our series. In the postoperative morbidity, we observed diaphragmatic eventration in 1 patient and we performed plication surgery on this patient. Surgical techniques for excision of tumors and cysts are shown in Table III.

\section{Discussion}

Although primary tumors and cysts of the mediastinum are seen in almost every age group, they are most common in the third decade [8]. In our case series, contrary to the literature, the average age was 39 and the most common group was the fourth decade. Six of our patients (23\%) came from abroad for treatment, especially from northern
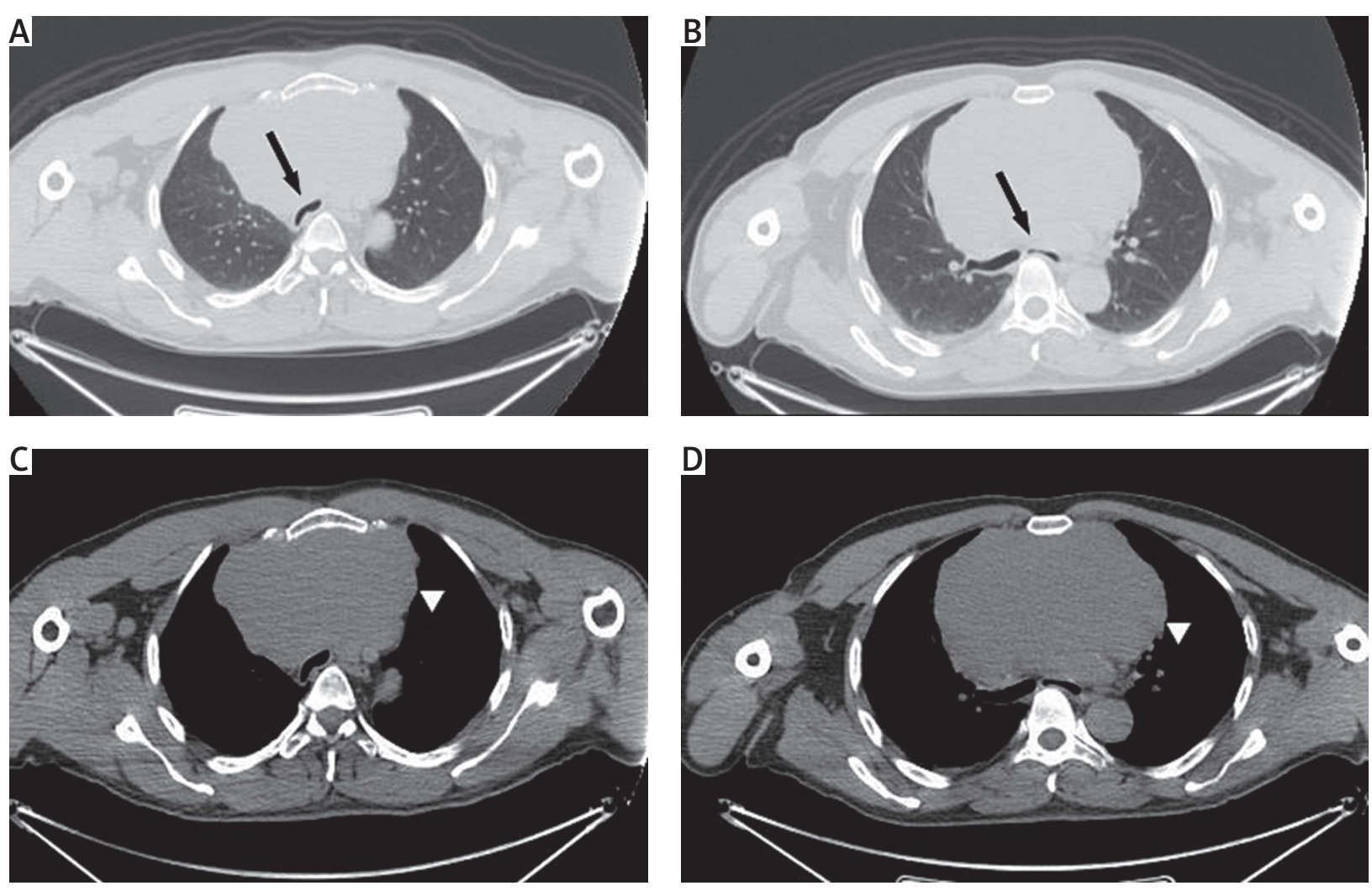

Figure 1. A, B - Parenchymal window of the thorax CT showing compression of the mass to the trachea and the main bronchi (arrows). C, D - The mediastinal window of the thorax CT showing a mass of about $15 \mathrm{~cm}$ in the anterior mediastinum (arrowhead) 
Iraq, and their mean age was 59.6 years. We think the reason for the high average age in our study was the high average age in the patients coming from abroad. We see that the patients in this group are diagnosed at an advanced age because of the poor development of the countries they come from and the insufficient diagnostic methods. In the literature, male sex was reported to be more frequent, and in our study, male gender was found to be $61.5 \%$ in 16 patients.

The majority of patients with mediastinal cysts or tumors are symptomatic $[8,9]$. In the Çakan et al. [9] study, $83 \%$ of the patients were found to be symptomatic. They may come with different symptoms depending on the location of the tumor. The most common findings are compression of the surrounding organs. Findings such as shortness of breath, hoarseness, dysphagia, or chest pain can be detected. As a result of tracheal compression, we can see a flattening in the spirometry curve revealing a plateau sign [10]. In our patient with a diagnosis of primary ante- rior mediastinal seminoma, severe tracheal and bronchial compression was present (Figure 1) and there was a plateau sign in spirometry. In our study, $80.2 \%$ of our patients were symptomatic and were admitted to hospital due to dyspnea (38.4\%).

Postero-anterior and lateral chest radiography is the first step for diagnosis of mediastinal tumors. Afterwards, contrast-enhanced thorax $\mathrm{CT}$, magnetic resonance imaging, positron emission tomography or scintigraphy can be used depending on the origin or location of the mass. Yasaka et al. [11] proposed the use of contrast-enhanced thorax CT in masses involving the anterior mediastinum in their study of 76 patients. They demonstrated that contrast-enhanced thorax CT has high specificity and sensitivity in the separation of solid and cystic masses. Contrast-enhanced CT is recommended for imaging of mature teratoma, mediastinal seminomas and mediastinal cysts [12].

Magnetic resonance imaging (MRI) is useful in demonstration of thymus hyperplasia and in the differentiation
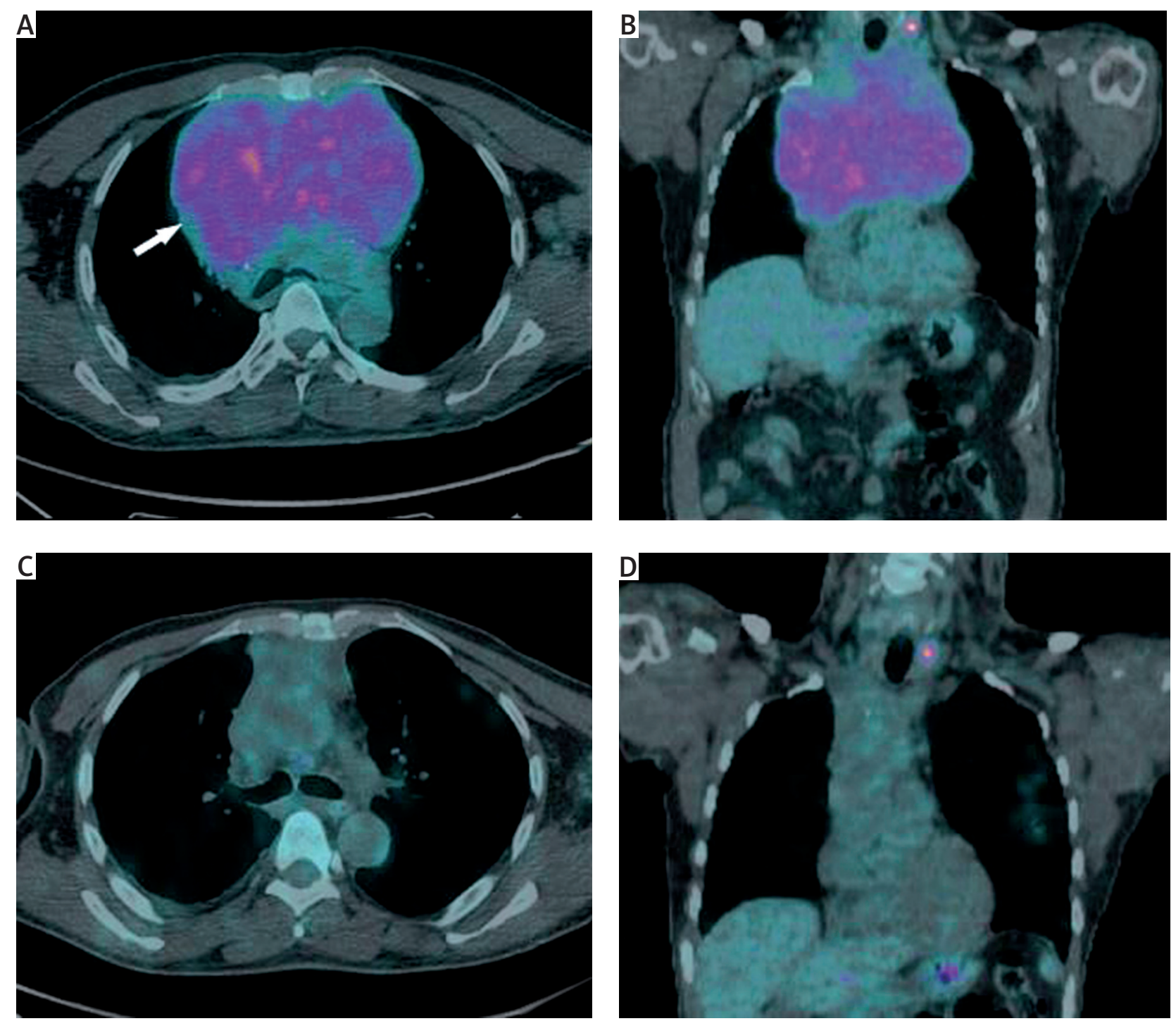

Figure 2. A, B - Axial and coronal sections of the PET CT showing high FDG uptake in the thyroid tissue and mediastinal mass (arrow). C, D - After chemotherapy PET-CT scan showing the full response in the mediastinal mass 
of thymic tumors. In contrast to noninvasive thymomas, invasive thymoma and thymic carcinomas have a more aggressive growth pattern. Local invasion and pleural invasion are a sign of invasive thymoma and can be clearly demonstrated by MRI $[13,14]$.

In our series, lymphomas were the most common malignant tumor with 4 patients (15.4\%). Takahashi et al. evaluated MRI and MRI in their studies evaluating contrast-enhanced CT, especially to evaluate the response of lymphomas after treatment and to show the presence of a residual mass [15]. MRI imaging is also useful in the diagnosis of neurogenic tumors such as schwannoma and paraganglioma. MRI findings of neurogenic tumors such as Schwannomas show hypointense or isointense on $\mathrm{T} 1 \mathrm{im}$ ages and high non-homogeneous signal intensity on T2 images $[16,17]$.

PET CT is recommended when malignant and benign discrimination is required in mediastinal tumors. In the Tatci et al. study, the sensitivity of PET CT was $90 \%$ and the specificity was $55.17 \%$. To distinguish malignant and benign lesions, the cut-off value of SUVmax was reported to be 4.67 [18]. The highest SUVmax value of our patients' PET-CT results was 20.1, and the mean SUVmax value was 11.6. We present PET-CT images before and after chemotherapy in our patient with primary mediastinal seminoma in Figure 2. He received 6 cycles of bleomycin, etoposide and cisplatin chemotherapy and then we found that there was a complete response in the mass with control PET CT (Figure 2).

Surgery is the mainstay of treatment for mediastinal cysts and tumors. There are different surgical approaches according to the location of the tumor. Thoracotomy, median sternotomy, VATS or robotic surgery techniques can be used in anterior and middle mediastinal masses [19-23]. VATS, thoracotomy or robotic surgery can be performed in the posterior mediastinal mass or cyst surgery [21-23].

Wang et al. [22] reported that they successfully performed mediastinal bronchogenic cyst excision with VATS in 108 patients. This case series, in which they shared their experience, required thoracotomy in only one patient. $\mathrm{Li}$ et al. [23] reported that robotic surgery could be used in all mediastinal areas in a series of 167 patients [23]. In our case series, VATS excision was performed in 15 (57.7\%) patients and surgery was performed with VATS-assisted minithoracotomy in 1 patient. Gossot et al. [24] have shown that VATS can be used reliably even in bulky mediastinal masses.

\section{Conclusions}

The role of robotic surgery and VATS-assisted surgery is increasing due to technological advances in surgery techniques. In addition, the rate of demanding minimally invasive surgical techniques increases with the increasing level of consciousness of the patients. With the publication of series with high numbers of cases, robotic and VATS surgery will be more frequently used as reliable techniques. In the surgical evaluation of mediastinal tumors, prospective studies with higher numbers of cases are needed.

\section{Disclosure}

The authors report no conflict of interest.

\section{References}

1. Priola SM, Priola AM, Cardinale L, Perotto F, Fava C. The anterior mediastinum: anatomy and imaging procedures. Radiol Med 2006; 111: 295-311.

2. Liu W, Deslauriers J. Mediastinal divisions and compartments. Thorac Surg Clin 2011; 21: 183-190.

3. Kuzucu A, Ozgel M, Erkal HS, Soysal O. Primary mediastinal cysts and masses: retrospective analysis of 31 cases. Inönü Tıp Derg 2003; 10: 15-19.

4. Sarper A, Gurkok S, Ozuslu BA, Genç O, Balkanli K. Primary mediastinal masses: analysis of 64 case. Türk Gögüs Kalp Damar Cer Derg 2001; 9: 153-155.

5. Michałowska I, Ćwikła J, Prejbisz A, Kwiatek P, Szperl M, Michalski W, Wyrwicz L, Kuśmierczyk M, Januszewicz A, Maciejczyk A, Roszczynko M, Pęczkowska M. Mediastinal paragangliomas related to SDHx gene mutations. Kardiochir Torakochirur Pol 2016; 13: 276-282.

6. Kermenli T, Azar C. Posterior mediastinal paraganglioma presenting with hypertension and back pain in a young adult. Kardiochir Torakochir Pol 2019; 16: 47-48.

7. Ayan E, Balci AE, Ozalp K, Duran M, Vuraloglu S, Cekirdekci A. Mediastinal masses: review of 27 cases. Türk Gögüs Kalp Damar Cer Derg 2005; 13: 127-130.

8. Cakan A, Yuncu G, Olgac G, Sevinc S, Askin M, Kaya SO, Alici H, Akdaag S. Retrospective evaluation of 53 cases with primary mediastinal tumors and cysts. Türk Gögüs Kalp Damar Cer Derg 2001; 9: 101-104.

9. Mayo Yáńez M, Esquía Medina GN, Vázquez Barro JC. Obstructive ectopic intratracheal thyroid. Acta Otorrinolaringol Esp 2017; 68: 372-373.

10. Yasaka K, Akai H, Abe O, Ohtomo K, Kiryu S. Quantitative computed tomography texture analyses for anterior mediastinal masses: differentiation between solid masses and cysts. Eur J Radiol 2018; 100: 85-91.

11. Willems E, Martens S, Beelen R. Robotically enhanced mediastinal teratoma resection: a case report and review of the literature. Acta Chir Belg 2016; 116: 309-312.

12. Marom EM. Advances in thymoma imaging. J Thorac Imaging 2013; 28: 69-80.

13. Carter BW, Benveniste MF, Truong MT, Marom EM. MR imaging of thymoma. Magn Reson Imaging Clin N Am 2015; 23: 165-177.

14. Takahashi K, Al-Janabi NJ. Computed tomography and magnetic resonance imaging of mediastinal tumors. J Magn Reson Imaging 2010; 32: 1325-1339.

15. Tekin G, Ozgel M, Tekin YK, Erbay AR. A rare cause of dyspnea and palpitations: mediastinal schwannoma. Kardiochir Torakochir Pol 2012; 9: 468-470.

16. Pavlus JD, Carter BW, Tolley MD, Keung ES, Khorashadi L, Lichtenberger JP $3^{\text {rd }}$. Imaging of thoracic neurogenic tumors. AJR Am J Roentgenol 2016; 207: 552-561.

17. Tatci E, Ozmen O, Dadali Y, Biner IU, Gokcek A, Demirag F, Incekara F, Arslan N. The role of FDG PET/CT in evaluation of mediastinal masses and neurogenic tumors of chest wall. Int J Clin Exp Med 2015; 8: 11146-11152.

18. Balci AE, Eren S, Eren N. Primary mediastinal tumors and cysts in adults: clinical evaluation of 61 cases and surgical results. T Klin J Med Sci 2003; 23: 33-37.

19. Puttorak R, Korlacki W, Pasierbek M, Grabowski A. Thoracoscopic resection of a bronchogenic cyst in a 17-year-old girl. Kardiochir Torakochir Pol 2016; 13: 370-372.

20. Ferrari G, Paci M, Sgarbi G. Thymolipoma of the anterior mediastinum: videothoracoscopic removal using a bilateral approach. Thorac Cardiovasc Surg 2006; 54: 435-437.

21. Lochowski MP, Brzeziński D, Kozak J. Videothoracoscopy in the treatment of benign neurogenic tumours of the posterior mediastinum. Videosurgery Miniinv 2014; 9: 315-318.

22. Wang X, Chen K, Li Y, Yang F, Zhao H, Wang J. The video-assisted thoracic surgery for mediastinal bronchogenic cysts: a single-center experience. World J Surg 2018; 42: 3638-3645.

23. Li H, Li J, Huang J, Yang Y, Luo Q. Robotic-assisted mediastinal surgery: the first Chinese series of 167 consecutive cases. J Thorac Dis 2018; 10: 2876 2880.

24. Gossot D, Izquierdo RR, Girard P, Stern JB, Magdeleinat P. Thoracoscopic resection of bulky intrathoracic benign lesions. Eur J Cardiothorac Surg 2007; 32: 848-851. 